\title{
Adult with infected spontaneous perinephric urinoma secondary to uro-obstruction by VUJ calculus: 'pop- off' mechanism
}

\author{
Karthik Shyam 도 , Dhilip Andrew 다 , Jovis Johny
}

Radiology, St John's Medical College Hospital, Bangalore, India

Correspondence to Dr Karthik Shyam; dr.karthikshyam@gmail.com

Accepted 10 December 2020

Check for updates

(C) BMJ Publishing Group Limited 2021. No commercial re-use. See rights and permissions. Published by BMJ.

To cite: Shyam K, Andrew D, Johny J. BMJ Case Rep

2021;14:e240390.

doi:10.1136/bcr-2020

240390

\section{DESCRIPTION}

An 18-year-old man presented with insidious, progressive right flank pain of 2-month duration, with fever of 2-week onset. Examination revealed right flank tenderness, with suspicion of ballotable right lumbar mass. No prior imaging had been undertaken. Blood examination revealed elevated leucocyte count $\left(11.2 \times 10^{9}\right.$ cells/L), high Erythrocyte Sedimentation Rate ( $85 \mathrm{~mm} /$ hour), with normal urinalysis. An unenhanced and contrast-enhanced CT scan of the abdomen with renal protocol was requested by the urologist.

Unenhanced study revealed a large calculus at the right vesico-ureteric junction (VUJ), causing mild right hydroureteronephrosis (figure 1A). A thick-walled right perinephric collection was seen, which showed irregular peripheral enhancement on administering contrast (figure 1B). This collection was noted to markedly compress and distort the kidney, with a mildly delayed nephrogram. Irregular defects in the right renal parenchyma were noted in the upper and interpoles (figure 1C). In the delayed phase, contrast was noted to seep through the aforementioned defects into the perinephric collection. Early rupture of this collection was seen into the right posterior pararenal fossa. Ultrasound done subsequently revealed a perinephric collection with debris and septation; and right renal Doppler evaluation showed elevated resistance flow. Left kidney was normal. Imaging diagnosis of infected spontaneous right perinephric urinoma secondary to obstruction by VUJ calculus was provided,

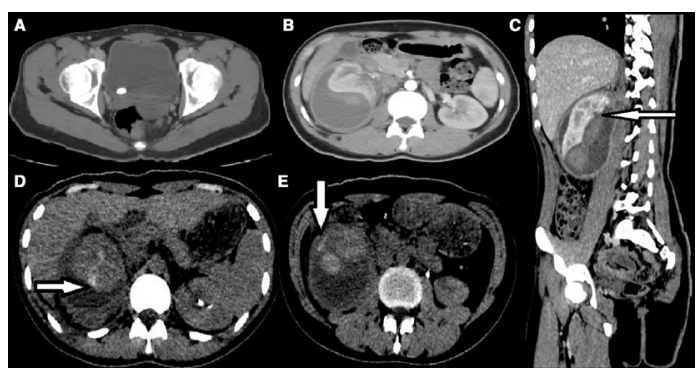

Figure 1 (A) Axial unenhanced CT of urinary bladder shows a large calculus at the right vesico-ureteric junction, (B) axial contrast-enhanced CT shows right infected perinephric collection causing compression of the right kidney, (C) sagittal reconstruction of contrastenhanced CT shows parenchymal defects (arrow), (D, E) delayed phase shows excreted contrast entering right perinephric collection, demonstrating communication with the collecting system. and subsequently confirmed by drainage of the collection.

A urinoma is a collection of urine in the perinephric space and usually is preceded by a definite history such as uro-trauma, malignancy or retroperitoneal fibrosis. ${ }^{1}$ Most urinomas are unilateral, with the rare bilateral presentation occurring secondary to posterior urethral valves, pelvi-ureteric junction obstruction or vesico-ureteric reflux ${ }^{2}{ }^{3}$; most often in the paediatric demographic. ${ }^{4}$ Various mechanisms are proposed for the formation of spontaneous urinomas secondary to obstruction: obstruction of the urinary tract leads to increased intrapelvic pressure, pyelosinus backflow with resultant rupture of the collecting system as a 'pop-off' mechanism leading to urinoma formation in the subcapsular or perirenal space. ${ }^{56}$

Imaging reveals varying degrees of hydroureteronephrosis (depending on the extent of decompression achieved), a perinephric collection that varies in complexity with presence of debris and septation, and a kidney that may be compressed and distorted owing to perirenal pressure. Doppler reveals elevated intrarenal resisitive index. Crosssectional imaging aids in revealing the level and aetiology of obstruction, in demonstrating the collection, possibility of abscess formation and renal function. Often, excreted contrast is seen to enter the perirenal collection (figure 1D,E).

Our patient underwent percutaneous drainage of perinephric purulent collection, which subsequently developed coagulase-negative Staphylococcus on culture. Calculus was removed via retrograde ureterostomy and double-J ureteric stent was placed. Patient is currently on follow-up with urology with drainage catheter in situ.

\section{Learning points}

Though rare, high index of suspicion for perinephric collection secondary to uroobstruction must be maintained under appropriate clinical scenarios.

- Ultrasound, Doppler and contrast-enhanced CT are the modalities of choice for imaging the aetiology of obstruction, size of collection and assessment of renal function.

- Management of the above lies in relieving cause of obstruction and drainage of perinephric collection, under antibiotic coverage. 
Contributors KS, DA and JJ were equally responsible for protocoling the study, interpreting the images and collecting patient data. KS was responsible for the content of the template. Patient consent was taken wherever deemed necessary.

Funding The authors have not declared a specific grant for this research from any funding agency in the public, commercial or not-for-profit sectors.

Competing interests None declared.

Patient consent for publication Obtained.

Provenance and peer review Not commissioned; externally peer reviewed.

\section{ORCID iDs}

Karthik Shyam http://orcid.org/0000-0003-0998-9604

Dhilip Andrew http://orcid.org/0000-0002-6154-3063

\section{REFERENCES}

1 Yang DM, Jung DH, Kim H, et al. Retroperitoneal cystic masses: CT, clinical, and pathologic findings and literature review. Radiographics 2004;24:1353-65.

2 McInerney D, Jones A, Roylance J. Urinoma. Clin Radiol 1977;28:345-51.

3 Pautler EE, Garvey FK. Perinephric cyst: report of case associated with ureteropelvic occlusion and congenital hydronephrosis. J Urol 1953;70:840-5.

4 Puri A, Bajpai M, Gupta AK. Bilateral spontaneous perinephric urinomas: case report and review of the literature. Urology 2004;64:590-1.

5 Macpherson Rl, Gordon L, Bradford BF. Neonatal urinomas: imaging considerations. Pediatr Radiol 1984;14:396-9.

6 Reinberg Y, Fleming T, Gonzalez R. Renal rupture after the Credé maneuver. J Pediatr 1994;124:279-81.

Copyright 2020 BMJ Publishing Group. All rights reserved. For permission to reuse any of this content visit

https://www.bmj.com/company/products-services/rights-and-licensing/permissions/

BMJ Case Report Fellows may re-use this article for personal use and teaching without any further permission.

Become a Fellow of BMJ Case Reports today and you can:

- Submit as many cases as you like

- Enjoy fast sympathetic peer review and rapid publication of accepted articles

- Access all the published articles

- Re-use any of the published material for personal use and teaching without further permission

\section{Customer Service}

If you have any further queries about your subscription, please contact our customer services team on +44 (0) 2071111105 or via email at support@bmj.com.

Visit casereports.bmj.com for more articles like this and to become a Fellow 